\title{
Retail
}

\section{Fifty-nine per cent of monthly portfolio value goes to retails - Q4, 2004!}

Recerved: 17 May 2005

\section{Bryan Duncan}

has been head of the retail division at Donaldsons, an independent property consultants in the UK and Europe, since November 1999. Bryan is responsible for heightening Donaldsons' retail presence, serving key clients and schemes and ensuring the continual contact with retailers and landlords alike. In particular, he provides expert advice on strategies for the development of and investment in shopping centres and other large-scale projects. Bryan is also chairman of Donaldsons Property Management, a 1,00o-person management company servicing leisure sites throughout the portfolio.

\section{Abstract}

The retail sector was again top during 2004 , with a total return of 21.7 per cent. The performance was achieved off the back of the strongest retail growth and largest fall in yields. Retail growth stocks outperformed value stocks, but value stocks' rentals did well. Retails continue to get the bulk of net investment: they now account for 59 per cent of monthly fund portfolio value. The retail sector should continue to deliver relatively strong returns.

\section{Keywords:}

retail sector, performance, delivery, retail growth stocks, shopping centres, shopping centre investment market

Bryan Duncan

Donaldsons

48 Warwick Street

London $W_{1} \mathrm{~B} 5 \mathrm{NL}$, UK

Tel: +44 (o) 2075348534

Fax: +44 (o) 2074340045

E-mail:

bryan.duncan@donaldsons.co.uk

\section{RETAIL INVESTMENT OUTLOOK}

The performance summary for last year is shown in Table 1. Returns were way above every forecast current at the turn of last year. The IPD's consensus of independent forecasts, ${ }^{1}$ for example, was for an all-property total return of 6.9 per cent, and $\mathrm{CBRE}^{2}$ suggested 5 per cent; several were, like these, predicting capital value falls.

In the strongest-performing sector, retails, the focus of attention now is the likely impact of house prices and consumer spending; the assumption is that their weakness threatens retail investment performance. Figures 1 and 2 highlight some recent economic and property trends.

Retail sales have proved to be a very unreliable guide to rental patterns. So too have house prices. Figure 3 shows that two years ago the average house price was $£ 121,400$. Since then it has 
Table I: Retall investment performance in 2004

\begin{tabular}{llll}
\hline \% per year & Rental growth & Capital growth & Total return \\
\hline Standard shops & 2.3 & 14.9 & 22.1 \\
Warehouses & 5.8 & 16.0 & 22.1 \\
Centres & 2.2 & 12.9 & 20.8 \\
\hline
\end{tabular}

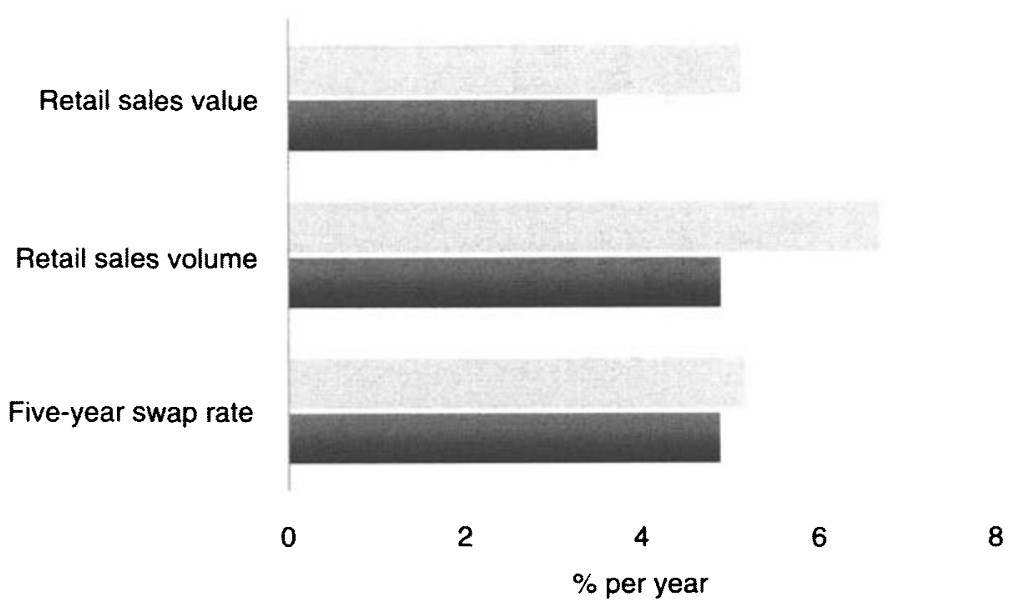

Figure 1: Economic trends

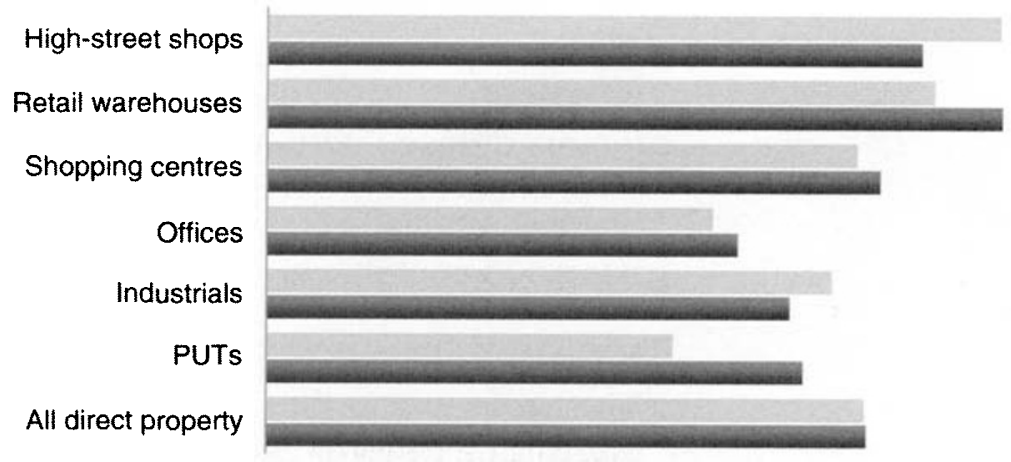

5

10

15

20

25

$\%$ six-month annualised total return

December 2004 September 2004

Figure 2: Property performance trends

increased by $£ 39,900$ ( 32.8 per cent), and then fallen back by an insignificant $£ 1,600$ to $£ 161,300$. This giant leap in value had no association with retail rental growth, which ran throughout at below its long-term average.

Looking forward, the main mortgage brokers are talking about stagnation rather than house-price decline, with the two leaders reporting minor price rises in December and January. The RICS is forecasting gains of a few per cent in $2005 .^{3}$

Figure 3 also shows that the volume of retail sales rose 11 per cent in the two-year period. Similarly to house prices, it would be 


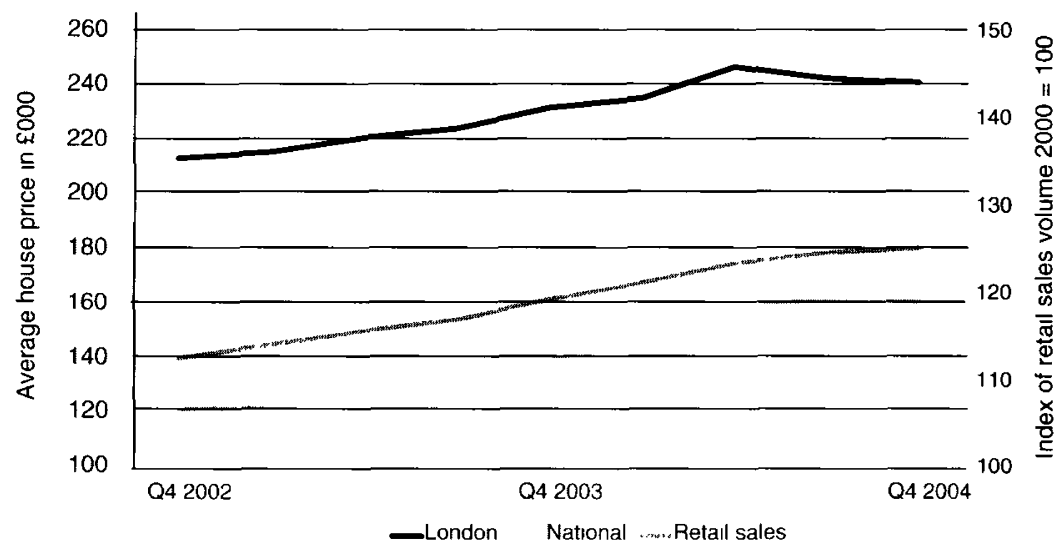

Source: $\mathrm{HBOS}$ and $\mathrm{ONS}^{4}$

Figure 3: UK house prices and retall sales

no great surprise if the very strong growth here also was followed by a calmer period. There may be trouble ahead, but subdued housing markets and retail sales are not an automatic threat to rents; poor retailer profitability, inflation and further tax rises after the election - seem more of a worry.

Meanwhile, the retail sector has the lowest void rate, the least over-renting, the greatest reversionary potential, the fastest rental growth, the fastest capital growth and the greatest institutional investment demand; its income returns are still 2.2 per cent above the five-year swap rate and are double equity's dividend. With high levels of employment and pay levels growing faster than inflation, the unemotional view of retail's performance in 2005 has to be for returns to continue to be in double digits.

\section{HIGH-STREET SHOPS}

The weakening in the rate of high-street rental growth that was evident for much of 2004 may be reversing. There was a revival in the growth rate during the final quarter for shops in all three quality bands. Retailer demand appears still to be falling and retail sales volumes and values are growing more slowly, making it uncertain how long the revival will last.

The decline in sales growth needs to be carefully interpreted, however. First, growth is still about as fast as at the start of 2004 . Secondly, the New Year sales figures have yet to be factored in, and these are now very much part of the winter shopping pattern, as people become more value-conscious. Thirdly, too much should not be assumed from sales growth figures anyway. The relationship such as it was - between retail sales growth rates and shop rental growth rates disappeared five years ago, at around the time price deflation set in, and has not been re-established. Recent retail sales and rental growth rates are compared in Figure 4.

Over 2004, the shops subsector delivered 2.3 per cent rental growth, which, with capital growth of 14.9 per cent, produced a 


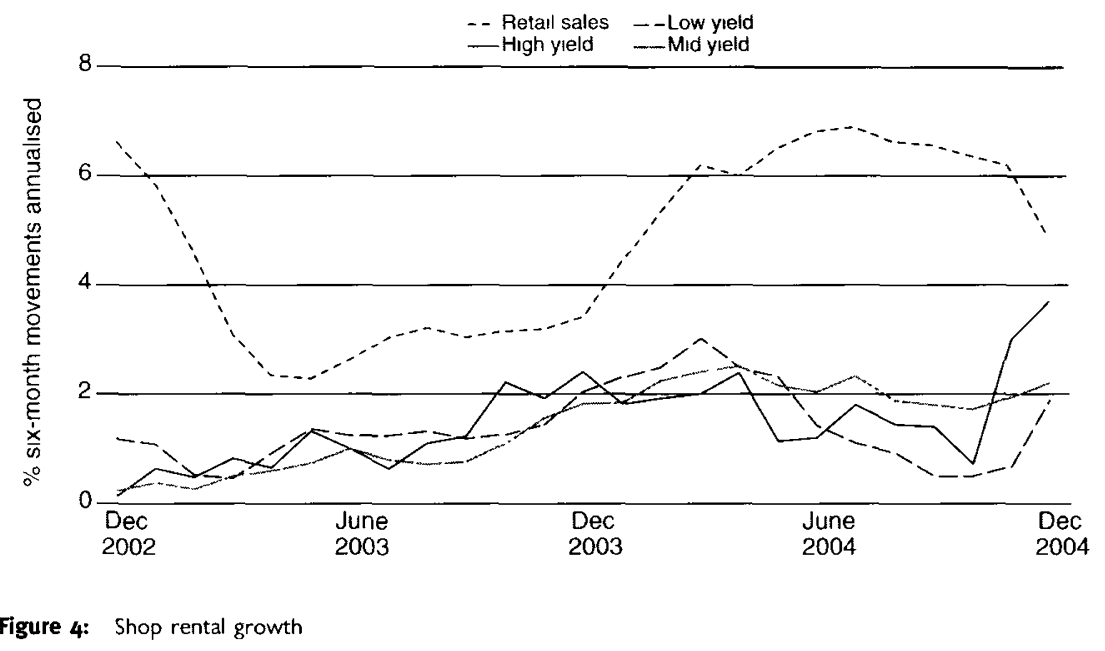

total return of 21.6 per cent for the year; this is up on the 15.1 per cent of the previous year. Performance at the year end, using sixmonth annualised figures, is shown in Table 2.

Table 2: Performance of shops subsector in 2004

\begin{tabular}{lccc}
\hline \% per year & High yield & Mid yield & Low yield \\
\hline Income return & 8.5 & 6.7 & 5.9 \\
Equivalent yields & 8.2 & 5.9 & 47 \\
Capital growth & 12.0 & 14.8 & 23.5 \\
Total return & 20.5 & 21.5 & 29.4 \\
\hline
\end{tabular}

The very strong investment performance is still being driven by declines in yield. This is likely to continue during the first part of 2005 at least, although as Figure 5 shows, the rate of capital growth coming from changes in yield is slowing down. Nonetheless, at the end of last quarter 2004 the effect of falling 'prime' shop yields was still boosting values by 22 per cent per year.

Retail sales trends are not reflected in shop rental growth, and so are not vital markers for short-term retail investment performance. Neither are they indicators of retailer profitability. They measure turnover levels and the rate of price inflation/deflation and should not be expected to tell one more.

The rates of volume and value growth have dropped to the levels of 12 months ago (see Figure 6). They will fall further, but are currently better than they were through virtually the whole of 2003 , a year in which retail sector rental growth doubled.

Nevertheless, sales growth is quite sharply down, and for some retailers this will have real consequences. Donaldsons ${ }^{5}$ issued a separate research note on Christmas trading 2004 earlier in 2005 which highlighted obvious 'losers' among retailers. As always in retail, however, there are those who buck the trend. 


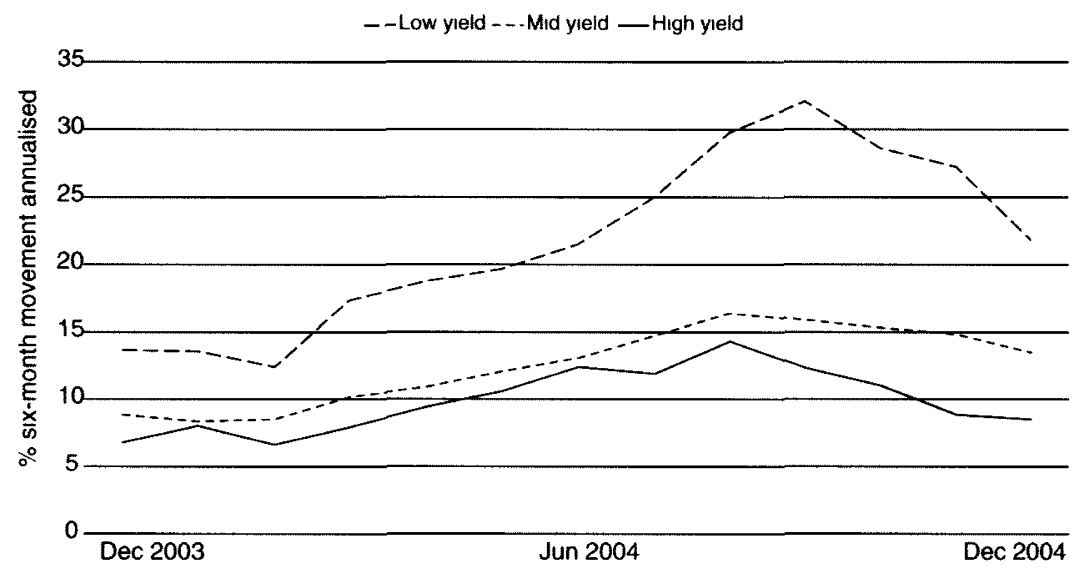

Figure 5: Capital gains from yield falls

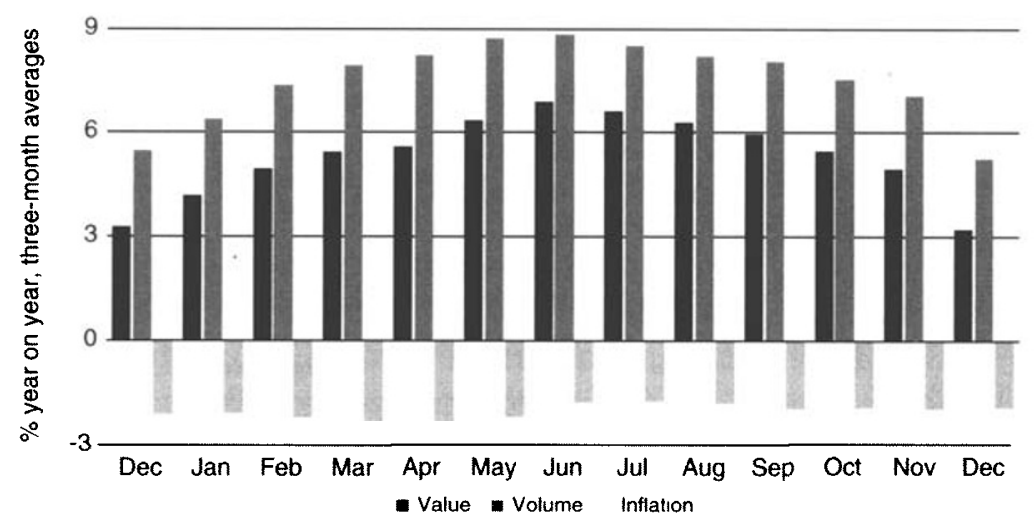

Figure 6: Retall sales - Non-food

\section{RETAIL WAREHOUSES}

Averaged across the whole retail warehouse subsector, there has been a fairly steady increase in the rental growth rate for the last three years, and it continues. Growth of 2.7 per cent in 2003 increased to 5.8 per cent in 2004. At the end of 2004, annual growth was running at 6.6 per cent on a six-month annualised basis (Figure 7).

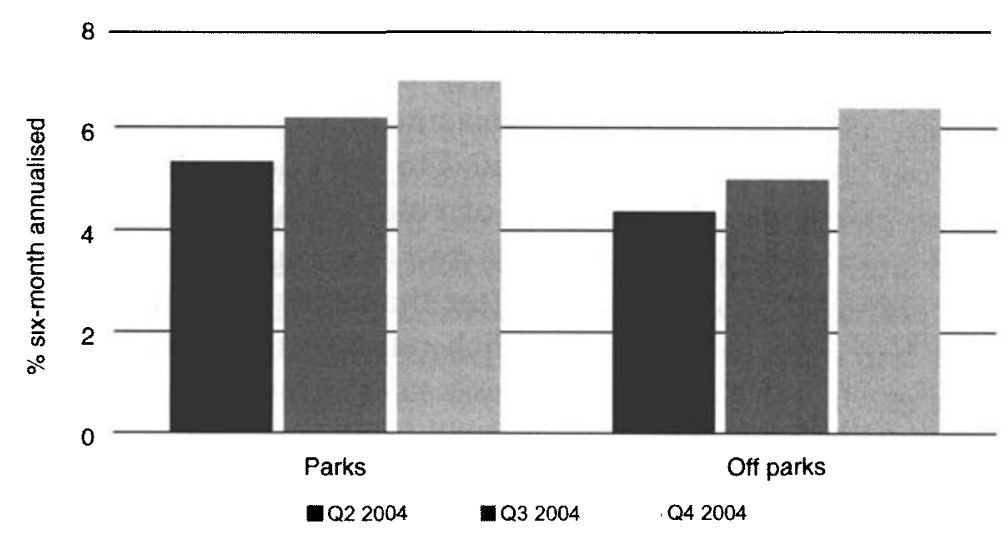

Figure 7: Retail warehouse rental growth 
Table 3: Retail warehouse yields

\begin{tabular}{lccc}
\hline \% per year & High yield & Mid yield & Low yield \\
\hline Income return & 7.2 & 6.7 & 5.7 \\
Equivalent yields & 7.7 & 6.0 & 5.4 \\
Yield Impact & 7.2 & 11.7 & 14.2 \\
Capital growth & 14.2 & 14.8 & 21.1 \\
Total return & 21.4 & 21.5 & 26.8 \\
\hline
\end{tabular}

Within the subsets monitored, the patterns of growth have not been surprising. Thus solus units have achieved the same average growth over the three years as have units on parks - something one has come to expect - and 'prime' units have beaten other types (see Tables 3 and 4).

Table 4: Rates of rental growth

\begin{tabular}{lll}
\hline \% per year & Last three years & At December 2004 \\
\hline Low yield & 5.6 & 8.5 \\
Mid yield & 3.3 & 3.7 \\
High yield & 1.8 & 5.8 \\
Parks & 4.2 & 6.9 \\
Solus & 4.1 & 6.4 \\
\hline
\end{tabular}

Figure 8 highlights two features that are less expected. First, the quality bands show growth rates moving with apparent degrees of lag. Secondly, there was a discernible change in the pattern of growth for the high-yielding 'value' stock in spring 2004. This may be the result of open consented, first- and second-generation stores being refurbished and relet at higher rents. Also, in parallel, more retailers are now targeting solus units and cheaper space, to focus on profitability rather than turnover.

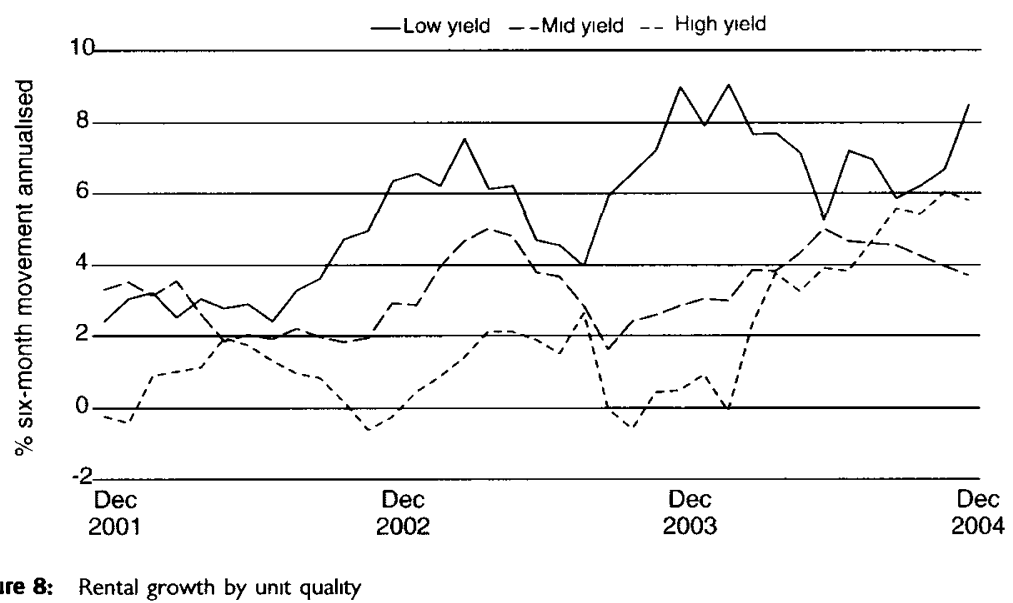




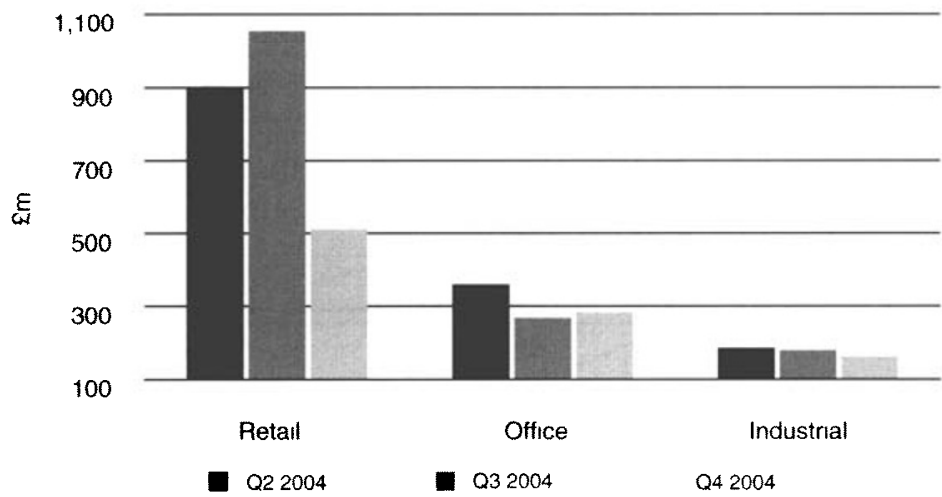

Figure 9: Net investment

\section{INVESTMENT ACTIVITY}

An increase in the level of sales and a decrease in expenditure prompted a large drop in the level of net investment into retails in the fourth quarter of 2004, compared with the previous two quarters' record sums. The sector took 'only' 53 per cent of the quarter's total net inflow. Retails now represent 59 per cent of IPD monthly fund portfolio values. ${ }^{6}$ The large bet on retail performance is not going to unwind quickly.

Net sums feeding into the offices and industrials sectors were similar in the fourth quarter to those in the third quarter, and overall the inflow in the last quarter of 2004 was down on the prior three months.

During the extraordinary year recently ended, retails took $£ 2.7 \mathrm{bn}$ ( 60 per cent) of the $£ 4.4 \mathrm{bn}$ fresh investment. The previous year, by contrast, at the lower prices then current, funds had divested from offices and barely moved their industrials quota, but had put $£ 0.8$ bn into retails (Figure 9).

\section{SHOPPING CENTRES}

At the end of the fourth quarter, centres were still marginally underperforming the other two retail subsectors. This confirms the overall performance through the year 2004 (Table 5).

Table 5: Shopping centres in 2004

\begin{tabular}{llll}
\hline \% per year & Rental growth & Capital growth & Total return \\
\hline Shops & 2.3 & 14.9 & 22.1 \\
Warehouses & 5.7 & 16.0 & 22.1 \\
Centres & 3.0 & 11.9 & 18.8 \\
\hline
\end{tabular}

Centre performances given here are for monthly valued funds' holdings plus those in funds valued quarterly, a sample that has increased 19 per cent in 12 months, but is still biased towards smaller schemes. 


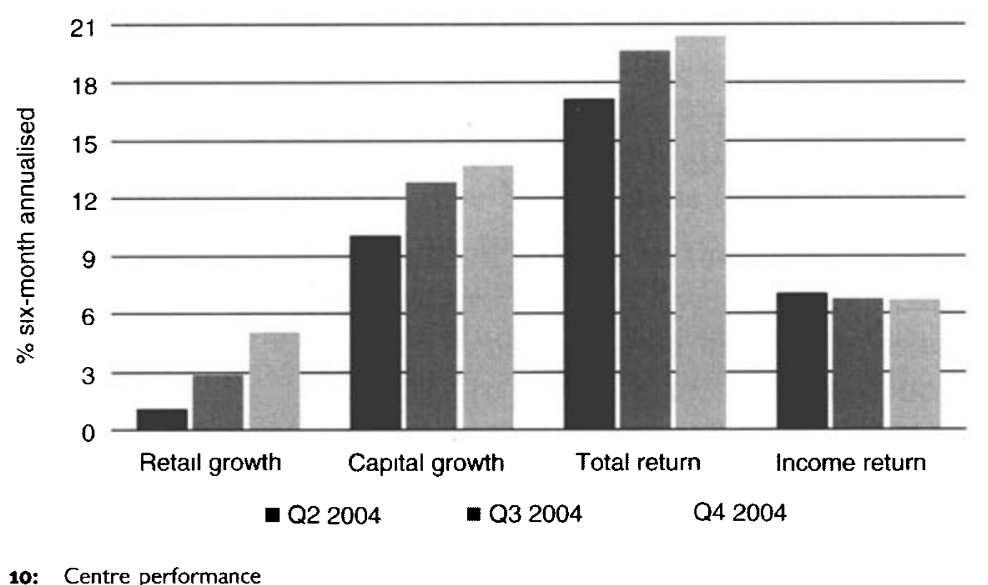

Figure 10: Centre performance

Centres, like shops and warehouses, improved their rate of rental growth over the final quarter of 2004, following a general downward trend in the first two quarters (Figure 10). Over 2004, centre rentals grew faster than high-street shops, repeating the experience of 13 of the last 16 years.

During the year, centre yields fell some 70 basis points, but there is only very slight evidence that the rate of yield decline is slowing. Meanwhile, their faster capital growth in the fourth quarter than in the third partly reflects the better rental growth that is feeding through. Capital growth and total return rates have now both increased for 16 quarters in a row.

Total returns from centres are now greater than at any time during the ten years for which Donaldsons has been running the series, and the overall annual return in 2004 of 18.8 per cent is the highest in the modern record, in inflation-adjusted terms; the likelihood of a repeat performance in 2005 is slim.

Figure 11 compares centre income returns, yields and the margin between income return and the five-year swap rate. Despite the hardening of yields and the fall in income return over 2004, the

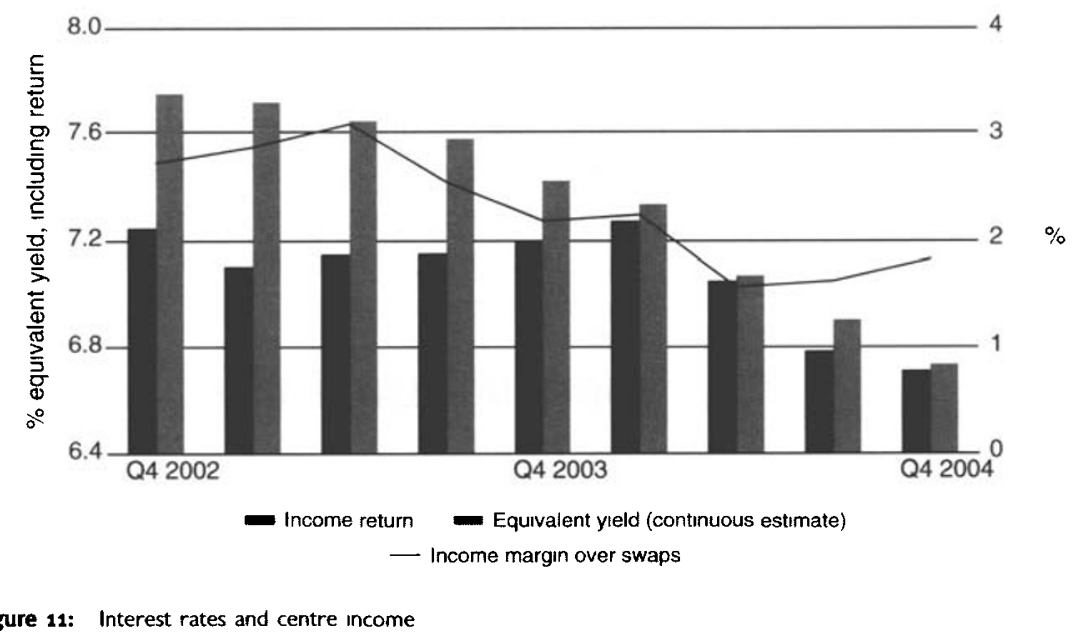




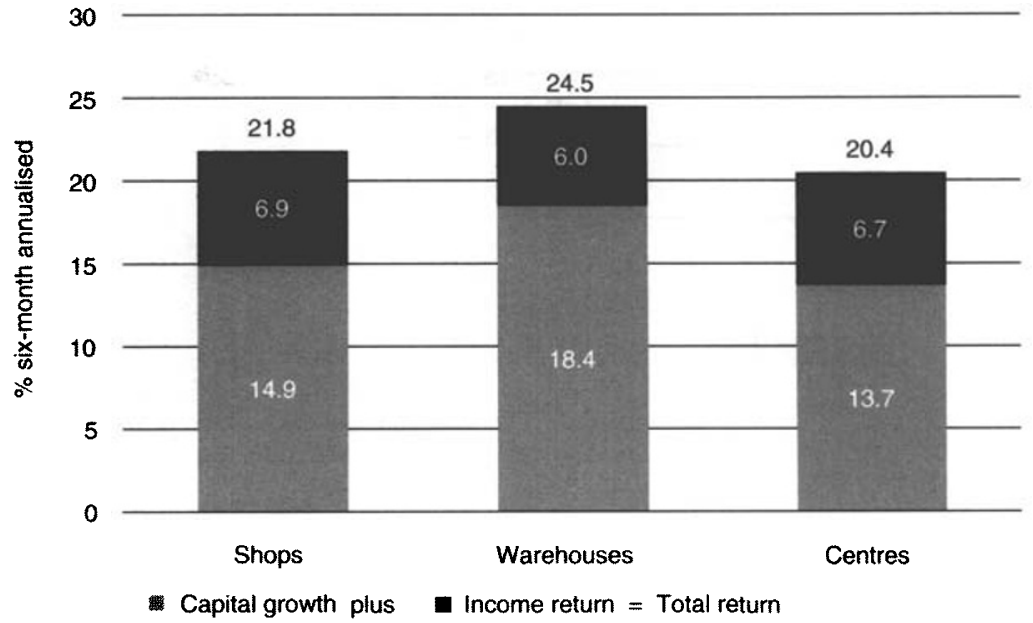

Figure 12: Sector performance summary (total returns)

18

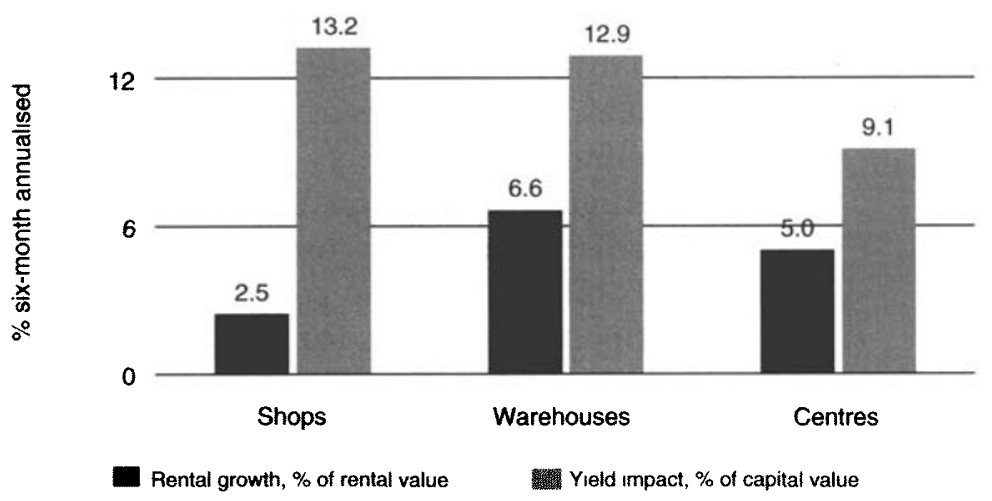

Figure 13: Sector performance summary (rental growth and yield impact)

extent of arbitrage is no weaker now than it was earlier in the year. Swap rates anticipated the change in the base rate's direction in autumn 2003, and in autumn 2004 the base rate levelled off at a lower rate than had previously been expected. From this perspective, with interest rate expectations currently pretty neutral, the short-term outlook for equivalent yields is steady, whatever their level relative to the past. Figures 12 and 13 detail a sector performance summary.

\section{SHOPPING CENTRE INVESTMENT MARKET}

The overriding message at the end of 2004 was for a cautious time ahead, with signs in the last quarter that some centres might take longer to sell, or possibly not sell at all. Investors were starting to react cautiously in expectation of poor retail sales over Christmas and showed a cautious appetite for anything but the clearest 
opportunities. The early signs in 2005 are that retail sales over the holiday period were mixed but not as dire as some commentators had anticipated, and that investors had recovered their zeal. This does nevertheless raise dilemmas for certain elements of the shopping-centre market.

For most of 2004 the weight of money in the secondary-centre market continued to put pressure on initial yields - typically 6-6.5 per cent. There is justification for these yield levels if investors have sound asset management plans to put in place, but they look questionable if investors are merely seeking a bolt-hole for surplus funds. For many investors the market still supports healthy returns without the need for capital investment in their assets -- indeed, for some it has provided a 'get out of jail free' card. But lack of investment plans and a willingness to invest will mean that the market will simply maintain current rent levels rather than achieve real growth. The low-return environment, with perhaps less scope than in recent years for further yield falls, will test owners' asset management skills to achieve and maintain satisfactory growth levels.

In contrast, the activity in the market for large lot size/prime shopping centres in 2004 appeared to support strongly both capital and rental growth, but was this faith being demonstrated in the form of market transactions? To a large extent this was answered in the fourth quarter with agreed sales of County Mall, Crawley (£190m), St Enoch Shopping Centre, Glasgow (£272.5m), Brunel Centre, Swindon $(£ 125 \mathrm{~m})$ and Main Square, Camberley $(£ 125 \mathrm{~m})$. Off-market activity saw Hammersons becoming 100 per cent owners of West Quay, Southampton ( $£ 203 \mathrm{~m})$ and the formation of the Scottish Retail Property partnership to acquire Southgate and Princes Square, East Kilbride. What is clear is that these large centres offer the opportunity for aggressive asset management and development plans, which may have been lacking in recent years and have perhaps been key factors in vendors' hold/sale judgments, despite such centres having, in many cases, been in the same ownership for several years.

Set against a squeeze on both household income and retailer margins, the continued weight of money will support the market across existing price and yield ranges. The initial yield/debt rate margin appears to have stabilised for stock below the prime sector and, as suggested, real growth will have to be achieved in a lowreturn environment that looks set to stay for the foreseeable future.

\section{TELLTALES ARE FLUTTERING}

An interesting battle is being waged in the retail investment market between the strong demand of the investor and the increasing weakness in consumer spending. On the face of it the surging demand from investors for shopping centres and retail parks looks misplaced alongside the increasingly gloomy outlook from retailers. But are investors more astute now than they were before the last 
crash in 1989 and the mini-crisis in 2000 ? One can look at the current state of play to find out.

The continued sluggishness in the equity market and memories of significant falls in 2002 have led more and more investors into the property market, either as direct players or indirectly through equity participation or property funds. With the office markets showing limited occupier demand, it is the retail market that is by far the most popular.

This surge in investment has seen yields fall to their lowest levels for over 20 years. But the low yields of the late 1980s were on the back of high inflation and implied a strong level of growth. Both inflation and growth are notably absent from this market.

During 2001 to early 2004 the majority of acquisitions were by experienced asset managers and property companies and most stock was traded out within two years, in accordance with a stated business plan policy. Since this time in 2004 the private investor and the institutions have been leading the way. These buyers tend to trade less and many will have no future sale plans, being content to sit on the return rather than look to push the property forward.

The experienced asset managers have delivered terrific results, but the yield shift has primarily been the driver, not just a well-executed asset plan. These purchases were made with high gearing, and the higher level of longer-term debt has eroded any financial margin against borrowing costs.

The current wave of investors is mainly either institutions with no debt borrowing, or wealthy investors with a low level of borrowing. They have less exposure to debt servicing requirements and can therefore outbid more highly geared competition.

More fundamentally, investors are finding lower returns acceptable. An equity return of 5-6 per cent is now regarded as the norm, rather than exceptional.

While the investment market is booming, the story is far less rosy along the malls. In recent months there have been several highprofile business failures and closures. Basebuy, parent company of Eisenegger and Foxhole, went into administration; Littlewoods has been closed and its stores are being sold; Trident Fashions, owner of Ciro Citterio, is in administration, as is Gadget Shop. Allders has disappeared and others are soon to follow.

There are many retailers reporting poorer-than-expected figures, including Argos, Kingfisher and WHSmith. Retail demand for new space is beginning to be affected by concerns about future trading. As might be expected, demand is strongest in the best locations in the top towns and cities. In secondary locations and in smaller towns demand is patchy at best.

There was confirmation of disappointing performance earlier this month when the CBI's monthly survey of retailers ${ }^{7}$ reported the weakest out-turn for retail sales volumes in 13 years. Forty-six per cent of the retailers surveyed said their sales volumes were down in 
the year to April, compared with 32 per cent reporting a rise. The balance of minus 14 was the lowest since July 1992.

Consumer spending is being squeezed by higher taxes and rising interest rates, and the re-election of a Labour government is likely to lead to a further rise in the tax burden and no realistic prospect of business growth in the short term.

The economies of the UK's European neighbours have been stagnant for some time, and it seems likely that the UK will follow their lead. Of greater concern is that the record high level of personal debt alongside reduced disposable income will lead to a period of recession rather than merely stagnation.

Investors may be happy with considerably lower returns and may feel that retail investment is the only credible asset class to invest in. Nonetheless, with the retail signs flashing amber they should proceed with caution.

\section{(C) Bryan Duncan}

\section{References}

1. IPD (2004) Consensus of Independent Forecasts.

2. Royal Institute of Chartered Surveyors (RICS) (2004) RICS Business, February, RICS, UK.

3. Donaldsons (2005) Retall Spotlight 4th Quarter 2004, May, Donaldsons, London, UK.

4. Ibid

5. Donaldsons (2004) Q4 Christmas Trading Update, Donaldsons, London, UK.

6. IPD, ref. 1 above.

7. Confederation of British Industry (CBI) (2005) Retail Sales Fall Again, CBI Survey, 3 May 